\title{
WASTE PACKAGE CORROSION STUDIES USING SMALL MOCKUP EXPERIMENTS
}

\author{
B.E.Anderson', K.B. Helean ${ }^{2}$, C.R. Bryan ${ }^{2}$, P.V. Brady ${ }^{2}$ and R.C. Ewing ${ }^{1}$ \\ 'Department of Geological Sciences, The University of Michigan, Ann Arbor, MI, USA \\ ${ }^{2}$ Sandia National Laboratories, Albuquerque, NM, USA
}

\section{Introduction}

The corrosion of spent nuclear fuel and subsequent mobilization of radionuclides is of great concern in a geologic repository, particularly if conditions are oxidizing. Corroding A516 steel may offset these transport processes within the proposed waste packages at the Yucca Mountain Repository (YMR) by retaining radionuclides, creating locally reducing conditions, and reducing porosity. Ferrous iron, $\mathrm{Fe}^{2+}$, has been shown to reduce $\mathrm{UO}_{2}{ }^{2+}$ to $\mathrm{UO}_{2(s)}$ [1], and some ferrous iron-bearing ion-exchange materials adsorb radionuclides and heavy metals [2]. Of particular interest is magnetite, a potential corrosion product that has been shown to remove $\mathrm{TcO}_{4}{ }^{-}$from solution [3]. Furthermore, if $\mathrm{Fe}^{2+}$ minerals, rather than fully oxidized minerals such as goethite, are produced during corrosion, then locally reducing conditions may be present. High electron availability leads to the reduction and subsequent immobilization of problematic dissolved species such as $\mathrm{TcO}_{4}^{-}, \mathrm{NpO}_{2}{ }^{+}$, and $\mathrm{UO}_{2}{ }^{2+}$ and can also inhibit corrosion of spent nuclear fuel. Finally, because the molar volume of iron material increases during corrosion due to oxygen and water incorporation, pore space may be significantly reduced over long time periods. The more water is occluded, the bulkier the corrosion products, and the less porosity is available for water and radionuclide transport. The focus of this paper is on the nature of Yucca Mountain waste package steel corrosion products and their effects on local redox state, radionuclide transport, and porosity.

\section{Work Description}

Six small-scale $(\sim 1: 40)$ waste package mockups were constructed using 316 stainless steel, a similar material to that proposed for Yucca Mountain inner waste packages (Fig. 1). Each mockup has an internal radius of $38.1 \mathrm{~mm}$, an internal length of $12.3 \mathrm{~mm}$, one lower port, and two upper ports. The two upper ports are used for the introduction of water through rubber septa, to prevent internal pressure build-up, and, in three of the mockups, to allow interactions with the atmosphere. The sampling port on the bottom has an Ultratorr fitting, into which a heavy-gauge $1.6 \mathrm{~cm}$ diameter glass test tube has been inserted for sample collection, and viton O-rings were used to seal the caps on both ends of a mockup. Each waste package mockup contains 25 strips $(1 \times 10 \times 0.2 \mathrm{~cm})$ of certified A-516 carbon steel. $9.525 \mathrm{~mm}$ diameter PTFE balls were used to separate the steel strips and to fill in the excess void space. 


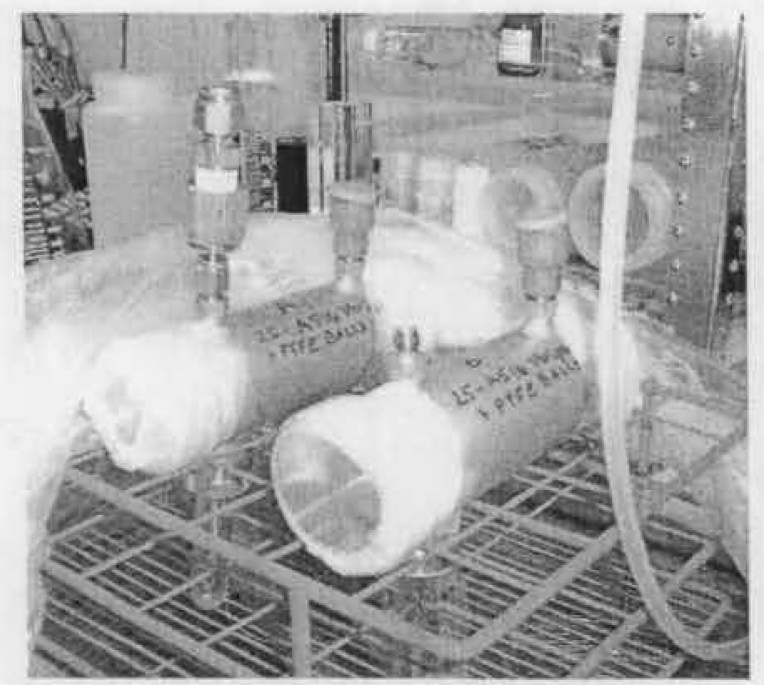

Fig. 1. Two 1:40 scale mockups with rubber septa and test tubes.

A simulated Yucca Mountain process water (YMPW) was injected into four of the mockups at a rate of $200 \mu \mathrm{l} /$ day, five days a week using a needle syringe. The YMPW consists of $50 \mathrm{mg} / \mathrm{L}$ silica as sodium metasilicate (and thus, $38.3 \mathrm{mg} / \mathrm{L} \mathrm{Na}$ ), enough hydrochloric acid to lower the $\mathrm{pH}$ to 7.6 , and an excess of powdered calcite. The solution was allowed to equilibrate open to the atmosphere for 5 days, filtered, and allowed to equilibrate with the atmosphere for an additional 5 days. The final $\mathrm{pH}$ stabilized at 7.5. A similar fluid, YMPW-2, a pH 7.9 dilute $\mathrm{Na}-\mathrm{Ca}-\mathrm{HCO}_{3}$ - silicate water with approximately $0.8 \mathrm{ppm}$ chlorine and $1.0 \mathrm{ppm}$ fluorine, was injected into the scoping study mockup at a rate of $1 \mathrm{~mL}$ per week.

All mockups except the scoping study were allowed to corrode at room temperature and at $>90 \%$ relative humidity. YMPW was injected into one of the two upper ports of all mockups except mockup $\mathrm{C}$, which was left open to the humid air to simulate waste package corrosion by condensation alone. The second ports remained open in mockups $\mathrm{B}$ and $\mathrm{E}$, while those of the final two mockups, A and D, were closed off using a swagelok "snubber" that allows gases to escape. Because of their increased access to the atmospheric oxygen, the "open" mockups are more likely to accurately simulate conditions at Yucca Mountain. Finally, uraninite, $\mathrm{UO}_{2}$, was used to simulate spent nuclear fuel in mockups D and E. The $0.1 \mathrm{~g}$ of uraninite in the mockups is roughly scaled by surface area to the spent fuel that will be present in the waste packages. The differences among the six waste packages are summarized in Table 1. 
Table 1. Test matrix for waste package mockup experiments. Mockups D and E were injected at the University of Michigan, while all other mockup studies took place at Sandia National Laboratories.

\begin{tabular}{|c|c|c|c|c|c|c|}
\hline Mockup & Atmosphere & $\begin{array}{c}\text { YMPW } \\
\text { Volume }\end{array}$ & $\begin{array}{c}\text { UO } \\
\text { present? }\end{array}$ & $\begin{array}{c}\text { Relative } \\
\text { Humidity }\end{array}$ & $\begin{array}{c}\text { Temperature } \\
\left({ }^{\circ} \mathbf{C}\right)\end{array}$ & $\begin{array}{c}\text { Duration of } \\
\text { Experiment }\end{array}$ \\
\hline A & Closed & $200 \mu \mathrm{l} /$ day & No & $75 \%$ & 25 & Ongoing \\
\hline B & Open & $200 \mu \mathrm{l} /$ day & No & $75 \%$ & 25 & Ongoing \\
\hline C & Open & - & No & $75 \%$ & 25 & Ongoing \\
\hline D & Closed & $200 \mu 1 /$ day & Yes $-0.1 \mathrm{~g}$ & $75 \%$ & 25 & Ongoing \\
\hline E & Open & $200 \mu \mathrm{l} /$ day & Yes $-0.1 \mathrm{~g}$ & $75 \%$ & 25 & Ongoing \\
\hline $\begin{array}{c}\text { Scoping } \\
\text { Study }\end{array}$ & Closed & $\begin{array}{c}1 \mathrm{~mL} / \text { week } \\
\text { YMPW-2 }\end{array}$ & No & $\mathbf{n / a}$ & 60 & $\begin{array}{c}\text { Sampled at } 30 \\
\text { and } 90 \text { days }\end{array}$ \\
\hline
\end{tabular}

Characterization of corrosion products included X-ray powder diffraction (XRD) and, where appropriate, scanning electron microscopy (SEM), transmission electron microscopy (TEM), X-ray photoelectron spectroscopy (XPS). Ferrous iron was measured in the solids using a standard $\mathrm{K}_{2} \mathrm{Cr}_{2} \mathrm{O}_{7}$ titration technique (Sandia ASTM D 3872-86) and in liquids using colorimetry. Effluents were also analyzed periodically using inductively coupled plasma mass spectrometry (ICP-MS).

\section{Results}

Corrosion products from the scoping study were analyzed using $\mathrm{XRD}$, titration for ferrous iron and SEM with energy dispersive spectroscopy (SEM-EDS). No free water was observed in the scoping study during its 90 -day duration.

Although the generally poor crystallinity of the corrosion products precludes reliable quantitative analysis of XRD data, major and minor phases were identifiable in the scoping study after 30 and 90 days. Magnetite, $\mathrm{Fe}_{3} \mathrm{O}_{4}$, possibly along with the structurally identical but fully-oxidized maghemite, was the major corrosion phase present after both 30 and 90 days. Titration showed that $4 \%$ of the corroded iron present was $\mathrm{FeO}$, confirming the presence of $12 \mathrm{wt} \% \mathrm{Fe}_{3} \mathrm{O}_{4}$. Hematite, $\mathrm{Fe}_{2} \mathrm{O}_{3}$, was observed as a minor phase in both cases, and after 90 days a mineral with (001) d-spacing of $12.87 \AA$ also appeared. All other peaks were matched to either magnetite or hematite, and this new phase could not be uniquely identified using XRD because of this significant preferred orientation along (001).

A polished cross-section of the 90 day corroded steel was characterized by SEM, with particular emphasis on this unidentified mineral. A backscattered electron micrograph shows oxidation "blisters" pock-marking the steel surface and clear zones that can be described as anodic (oxidizing) and cathodic (reducing) (Fig. 2A). The unidentified phase is a large mass composed of loosely consolidated fibers above the oxidizing zone (Fig. 2B). EDS indicate that the $\mathrm{Cl}$ is preferentially incorporated in this "fibrous" phase, and micrographs suggest a layered structure. 


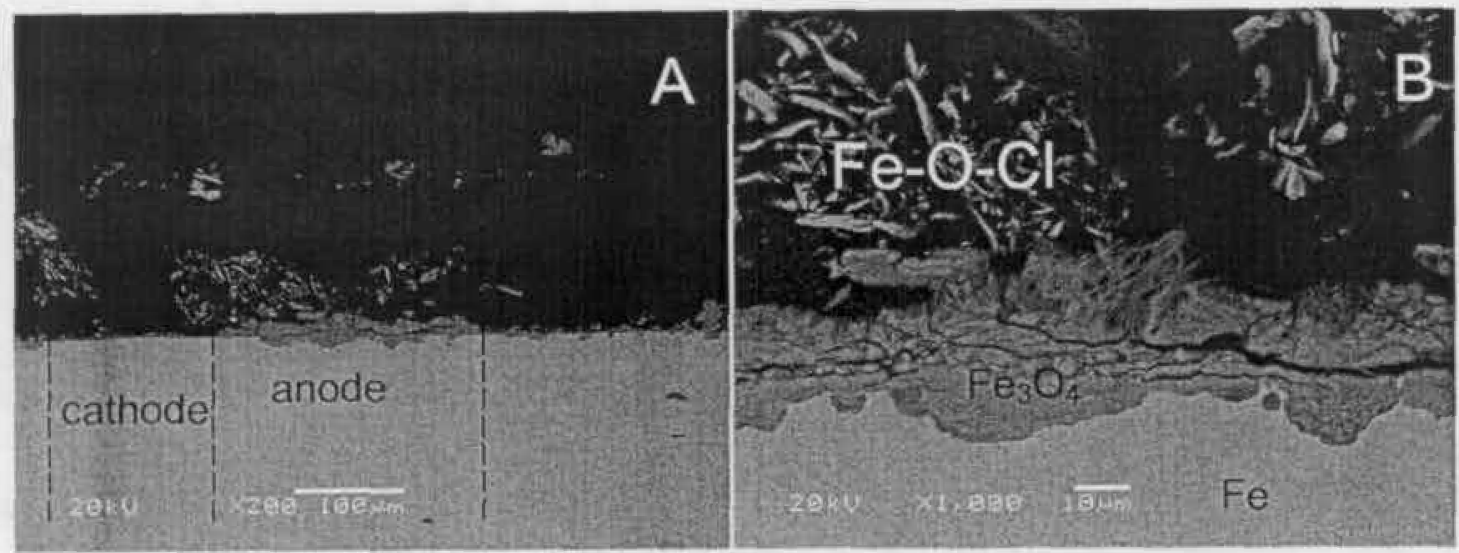

Fig.2. Backscattered electron micrographs of the steel after a 90 day corrosion test. "Blisters" of oxidation mark the surface of the sample with regions of anodic and cathodic character (A). The loosely consolidated fibers are enriched with chlorine relative to the other corrosion products (B).

\section{Conclusions and Discussion}

Results from the scoping study suggest that magnetite will be an important corrosion product, and the ferrous iron in magnetite suggests that the in-package environment will be at least somewhat reducing. Hematite is not expected to be present in significant amounts in the remaining mockups because hematite formation occurs almost entirely at elevated temperatures [4].

If a phase similar to the Cl-bearing phase forms, it may be important for the uptake of radionuclides and in maintaining a reducing environment because the observed morphology, chemistry and interlayer $d$-spacing suggest that this phase may be related to green rust, a layered Fe-oxyhydrate containing both ferrous and ferric iron. Green rusts have been shown to remove over $99.8 \%$ of of pertechnetate from solution [5]. Also, because green rust is unstable in an oxidizing environment [1], its presence would provide strong evidence for locally reducing conditions. The reported (001) interlayer spacing for the perchlorate stabilized green rust is $11.02 \AA, 1.85 \AA$ smaller than that of the $\mathrm{Cl}$-rich phase observed in the scoping study. Also, the XRD data contain no peaks associated with lepidocrocite, a typical oxidation product of green rusts. Additional analyses including TEM with selected area electron diffraction (SAED) will be conducted in order to determine the precise nature of the $\mathrm{Fe}-\mathrm{O}-\mathrm{Cl}$ phase.

Discussion of the corrosion products' impact on radionuclide corrosion/transport and porosity cannot be made at this time because the relevant experiments are still in progress.

The presence of reduced iron in magnetite and possibly also a variant of green rust in waste package mockup studies suggests that these radionuclide-sorbing minerals will be present in Yucca Mountain waste packages, and the large amounts of reduced iron will cause locally reducing conditions. Ongoing experiments with $\mathrm{UO}_{2}$ and XPS studies of 
occluded water will provide further insight into the effects of A516 steel corrosion products on radionuclide transport and in-package porosity. This study suggests that steel and its corrosion products may represent a substantial barrier between uranium and other radionuclides in Yucca Mountain waste packages and the environment.

\section{References}

1. Cornell, R.M., and Schertmann, U. (2003) The Iron Oxides: Structure, Properties, Reactions, Occurrances and Uses. Wiley-VCH GmbH \& Co. KGaA.

2. Cui, D.Q. and Eriksen, T. E. (1996) Reduction of pertechnetate by ferrous iron in solution: Influence of sorbed and precipitated Fe(II). Environmental Science \& Technology, 30, 7, 735-743.

3. Navratil, J. D. (1989) Ion-exchange technology in spent fuel-reprocessing. Journal of Nuclear Science and Technology, 26, 8, 735-743.

4. O’Loughlin, E., Kelly, S.D., Cook, R.E., Csenscsits, R., and Kemner, K.M. (2003) Reduction of uranium(VI) by mixed iron(II)/iron(III) hydroxide (green rust): formation of $\mathrm{UO}_{2}$ nanoparticles. Environmental Science and Technology, 37, 721-727.

5. Pepper, S.E., Bunker, D.J., Bryan, N.D., Livens, F.R., Charnock, J.M., Pattrick, R.A.D., Collison, D. (2003) Treatment of radioactive wastes: An X-ray adsorption spectroscopy study of the reaction fo technetium with green rust. Journal of Colloid and Interface Science, 268, 408-412. 